\title{
Intraseasonal Oscillations during the TOGA-COARE IOP
}

\author{
By Tetsuo Nakazawa \\ Meteorological Research Institute, 1-1 Nagamine, Tsukuba, Ibaraki 305
}

(Manuscript received 31 August 1994, in revised form 14 February 1995)

\begin{abstract}
We examined the behavior of the convective activity and other meteorological variables such as divergence, velocity potential and total precipitable water, associated with the intraseasonal oscillation (ISO) during the TOGA-COARE IOP from November 1992 to February 1993.

During the IOP, there are two major ISOs, one in December and another in January. We confirmed that there is a hierarchic structure of the tropical convection: planetary-scale ISO, eastward-moving synopticscale super cluster, and westward-moving meso-scale cloud cluster. Each ISO has two super clusters. The maximum of the total precipitable water (tpw) delineated from the SSM/I data is leading the convective activity from the GMS IR TBB data by about 5-10 days. The SST is also leading the convection about by $12-13$ days, which is the same as for previous results.

We also checked the surface radiation budget. The SST change is closely related with the ISO passage. The clear sky and the calm wind condition leads to the warming up of the SST east of the active convection associated with the ISO (that is, before the passage of the active convection of the ISO). During the passage of the active convection associated with the ISO, the SST decreases due to less insolation and enhanced latent heat flux from the sea surface under the disturbed wind condition.
\end{abstract}

\section{Introduction}

Toward the understanding of the ocean-atmosphere coupling mechanism over the warm water pool region in the western Pacific, the international program of TOGA (Tropical Ocean and Global Atmosphere)-COARE (Coupled Ocean and Atmosphere Response Experiment) was performed during the period of November 1992-February 1993. One of the key issues of the program is to determine the structure of the synoptic and mesoscale components of the large-scale, slowly varying atmospheric circulation in the warm pool, in particular to determine the morphology of the most convective stage of the 30-60-day mode and its sub-components (TOGACOARE Operation Plan, 1993). This paper focuses on the topic by using not only the global analysis dataset but also the total precipitable water (tpw) from the satellite, the global sea surface temperature (SST) dataset and the surface flux dataset.

First we will try to figure out the behavior of the convective activity during the TOGA-COARE IOP. Nakazawa (1986) showed that the planetary-scale, eastward-moving intraseasonal oscillation (ISO) consists of the synoptic-scale, eastward-moving super clusters with a horizontal extent of convective area of several thousand kilometers. Nakazawa

(C)1995, Meteorological Society of Japan
(1988) further showed evidence that the super cluster has its internal structure: westward-moving cloud clusters. The periodicity of the cloud cluster is about 1-2 days. Recently Takayabu (1994a) analyzed the predominance of the westward-moving cloud disturbance with a period of about 2 days by using the 10-year data of the infrared equivalent blackbody temperature (IR TBB) of the Geostationary Meteorological Satellite (GMS) and identified the disturbance as an $n=1$ westward-propagating inertio-gravity wave mode. Takayabu (1994b) suggested that the westward-moving cloud cluster of the super cluster can be interpreted in terms of this mode. Hendon and Liebmann (1994) stressed that very little synoptic variance associated with the ISO is accounted for by super clusters, thus questioned the role of the super cluster in the excitation and propagation of the ISO. However, if we see the Hovmoller diagram of the high-resolution (3-hourly) global cloud imagery (GCI) of their Fig. 9, we notice that most of the super clusters with westwardmoving cloud clusters can be found during the active phase of the ISO. The figure definitely represents that the super cluster is a key component of the ISO. The role of the super cluster in the excitation and propagation of the ISO is still one of the key and open issues of the ISO. However, we do not doubt that the ISO co-exists with super clus- 

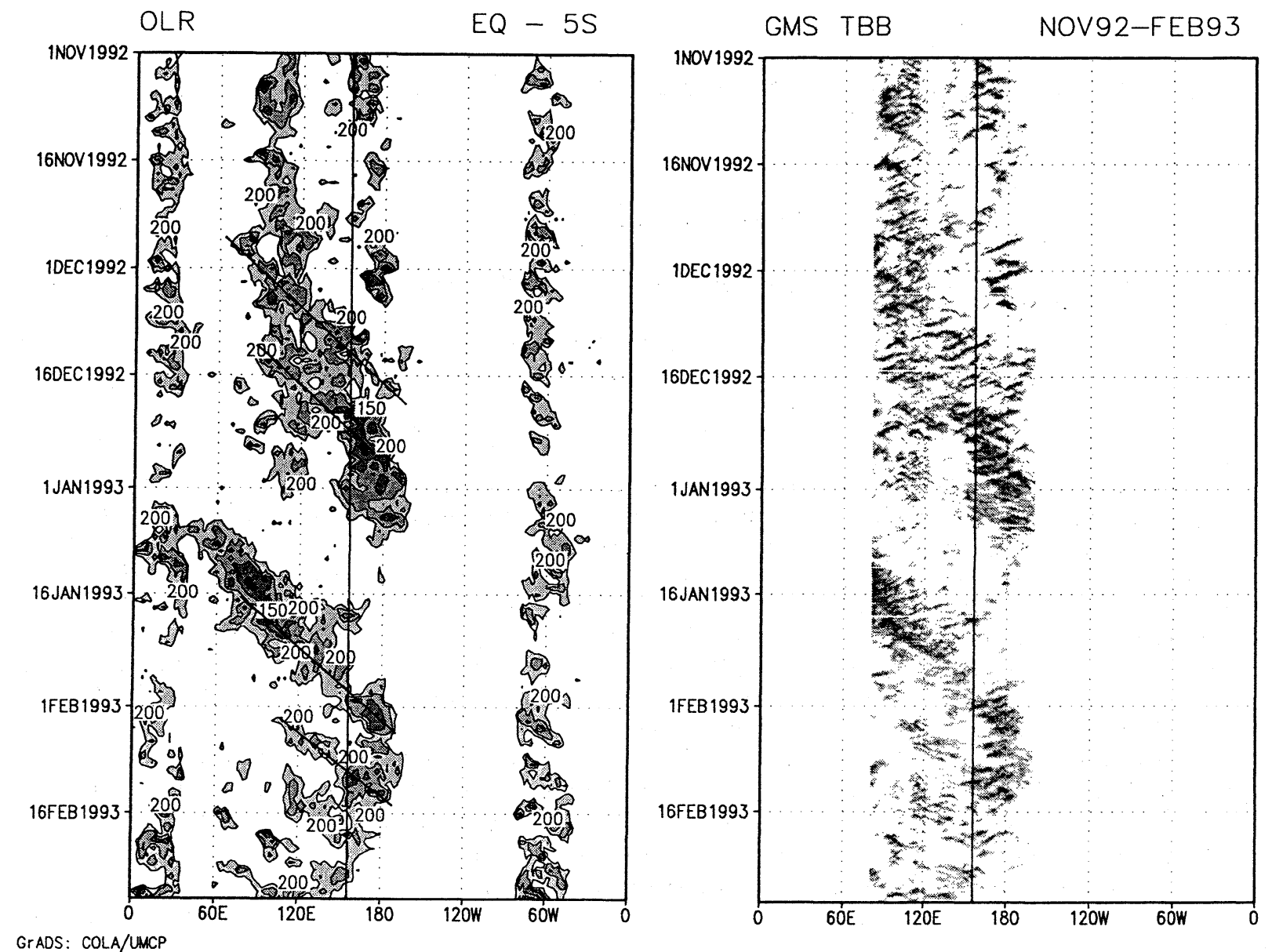

Fig. 1. Time-longitude section of the outgoing longwave radiation (OLR) (left) and the GMS IR TBB (right) averaged between the equator and $5^{\circ} \mathrm{S}$ during the TOGA-COARE IOP from November 1 , 1992 to February 28, 1993. For the OLR data; The contour is drawn only where the value is less than $200 \mathrm{Wm}^{-2}$. The interval is $25 \mathrm{Wm}^{-2}$. For GMS data, shading denotes the area of cooler than $260^{\circ} \mathrm{K}$. The dark shading is for less than $210^{\circ} \mathrm{K}$. The slanted lines are the center longitudes of super clusters, which are subjectively determined. The vertical line is $156^{\circ} \mathrm{E}$, the center longitude of the IFA.

ters. Moreover, the TOGA-COARE program will provide a good dataset for the study. For example, precise dataset of moisture, SST, surface flux etc. is required for the extensive study to understand the morphology of the 30-60-day mode and its subcomponents. Although at present the availability of these data is limited, this paper aims to reveal the sub-components of the ISO during the TOGACOARE IOP and to examine the moisture field, SST field, and surface flux field, which are closely related with the excitation and propagation mechanism of the ISO.

In Section 2, we describe the data we used in this study. In Section 3, the main results are shown: first we demonstrate the hierarchic structure of the tropical convective activity, then show the overview of the ISOs during the 4-month period of the TOGACOARE IOP by using the global dataset, and examine the phase relationship between the moisture and the convection associated with the ISO. Finally we show the surface flux data over the Intensive Flux Array (IFA) centered at $2^{\circ} \mathrm{S}, 156^{\circ} \mathrm{E}$ to see the SST change and its relation to the convection and the surface wind speed. In Section 4 we summarize the results.

\section{Data}

The data we used in this study are as follows:

- The GMS IR TBB data on a $1^{\circ} \times 1^{\circ}$ grid at 3-hourly intervals.

- Outgoing longwave radiation (OLR) data from the NOAA orbiting satellites.

- The Japan Meteorological Agency (JMA)/global analysis dataset (GANAL) with a $1.875^{\circ}$ grid, conventional variables at 11 levels. Divergence and velocity potential are calculated 



GrADS: COLA/UACP

Fig. 2. Time-longitude section of zonal wind fields at $200 \mathrm{hPa}$ (left) and $850 \mathrm{hPa}$ (right) averaged between the equator and $5^{\circ} \mathrm{S}$. Light shading denotes the area of less than $-10 \mathrm{~ms}^{-1}$. Dark shading denotes the area of more than $20(0) \mathrm{ms}^{-1}$ for $200(850) \mathrm{hPa}$. The slanted lines are the same as Fig. 1 (left).

from the wind fields. Total precipitable water (tpw) is also calculated.

- The JMA/Numerical Prediction Division (NPD) global SST dataset with a $2.5^{\circ}$ grid. The climatological SST and anomalous SST are included.

- The JMA/NPD global sea surface flux dataset.

- Daily mean values of total precipitable water from SSM/I of the DMSP satellite delineated from Wetnet algorithm with about $0.5^{\circ}$ resolution.

\section{Results}

a. Hierarchic structure of tropical convective activity Figure 1 is the time-longitude section of the OLR (left) and the GMS IR TBB (right) averaged between the equator and $5^{\circ} \mathrm{S}$ during the TOGACOARE IOP. Over the tropics the low OLR values may correspond to the active convection. Keep in mind that the temporal and spatial resolution for both datasets is different. The OLR data are daily with a 2.5 degree lat./lon. grid, and the GMS is 3hourly and 1 degree. Two eastward-moving, active large-scale convections associated with the ISOs are evident in the figure. The first one is found over the Indian Ocean $\left(80-100^{\circ} \mathrm{E}\right)$ in early December and propagated eastward, reaching over the western or central Pacific in early January. The propagation speed became slow when approaching to the dateline. The active convective area stayed near the dateline in early January. The second one originated from $60^{\circ} \mathrm{E}$ over the Indian Ocean in early January and also moved eastward to the central Pacific in early February. Notice that the eastward-moving ISO consists of the eastward-moving synoptic active convective regions, which are called super clusters, whose axes of the maximum convective activity are drawn subjectively by the solid lines in the OLR figure. The eastward-moving phase speed of the super cluster is about $6 \mathrm{deg} /$ day. Also, in the higher temporal and spatial resolution data of the GMS IR TBB data (Fig. 1, right), it can be seen that a super 



Fig. 3. Same as Fig. 2, except for the velocity potential fields. Light (dark) shading denotes the area of less (more) than $-5(5) \times 10^{6} \mathrm{~m}^{2} \mathrm{~s}^{-1}$.

cluster consists of the westward-moving cloud clusters with a life cycle of about 2 days or so. There is a difference in the convective activity of the two ISOs. The convection of the first ISO is active over the western and central Pacific around the end of December. On the other hand, the convection of the second ISO is active in the Indian Ocean in the middle of January. The puzzling feature of the convective activity in the figure is the existence of the "westward-moving" super cluster found in the central Pacific along the equator (not clear in $5^{\circ} \mathrm{S}$ after the first ISO) around early January and early February between $150^{\circ} \mathrm{E}$ and $170^{\circ} \mathrm{W}$ after the "eastwardmoving" super cluster reached over the central Pacific. The phase speed of the westward-moving super cluster" is 3 degrees/day after the first ISO and 2 degrees/day after the second ISO, which is slower than the one of the eastward-moving cases.

The diurnal cycle of the convection is evident at $110^{\circ} \mathrm{E}$ and at $140^{\circ} \mathrm{E}$. The former corresponds to Borneo and the latter to New Guinea.

\section{b. Global features of an ISO revealed by using the JMA dataset}

The GMS data covers from $80^{\circ} \mathrm{E}$ to $160^{\circ} \mathrm{W}$, about $1 / 3$ of the globe. Although the GMS covers the most important area of the convective activity for climate and warm-water pool studies, we need to examine the global behavior of an ISO on a planetary scale by using the twice-daily JMA/GANAL global analysis dataset

Figure 2 shows the time-longitude section of the zonal wind averaged between the equator and $5^{\circ} \mathrm{S}$ over the globe at $200 \mathrm{hPa}$ (left) and $850 \mathrm{hPa}$ (right). Figure 3 shows the same as Fig. 2, except for the velocity potential fields calculated from the divergence fields. In these figures we also add the phase propagation line of the super clusters as shown in Fig. 1. The active convective regions correspond well with lower-level westerlies and convergence (upper-level easterlies and divergence). The upper-level easterlies and divergence show the fine structure associated with the super cluster. Although we have not computed the upward motion field, Fig. 3 suggests that there is a large-scale upward motion in 

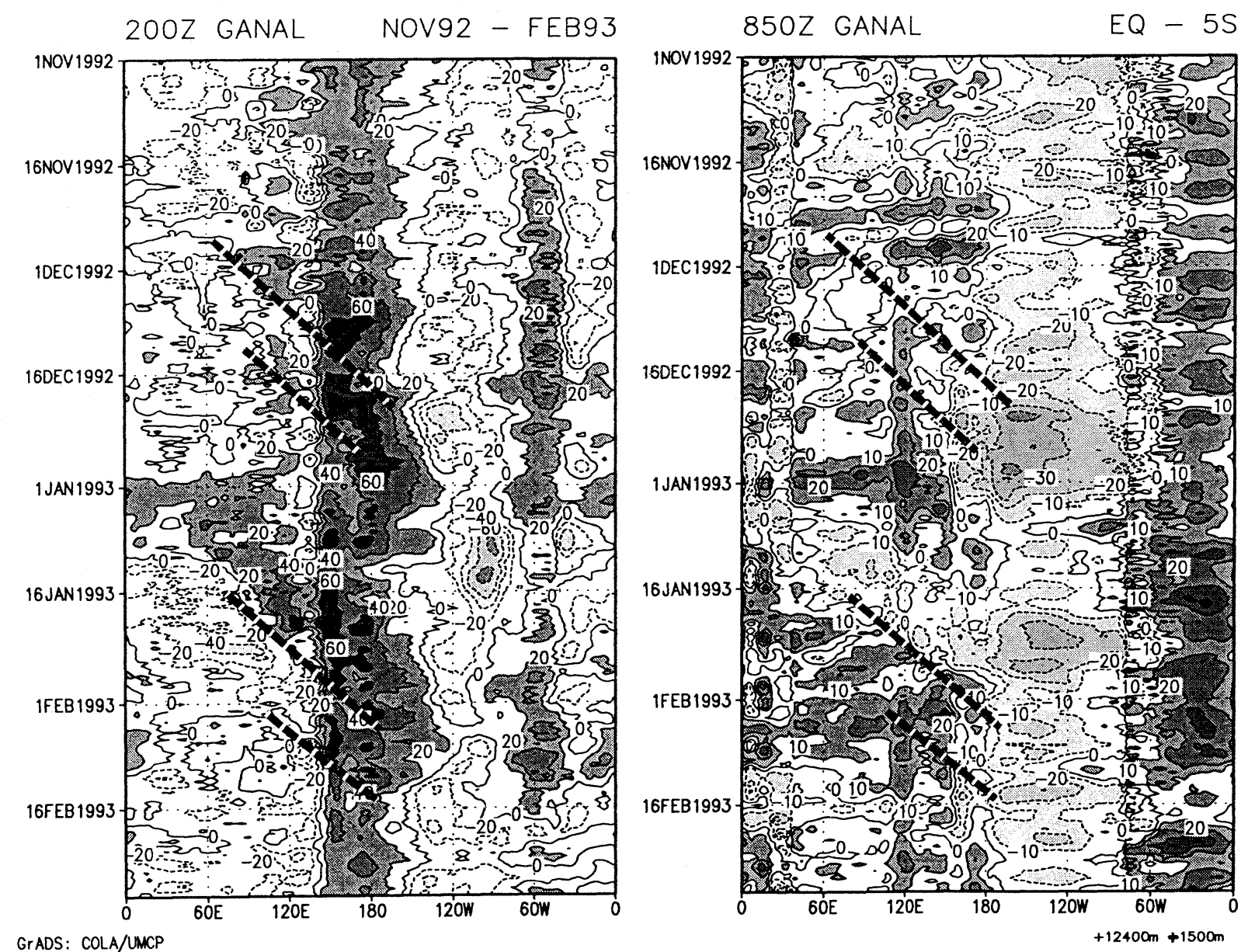

GrADS: COLA/UMCP

Fig. 4. Same as Fig. 2, except for the geopotential height fields. The offset is $+12,400(+1,500) \mathrm{m}$ for $200(850) \mathrm{hPa}$. The real height value is obtained by adding the offset value. Light (dark) shading denotes the area of less (more) than $10(20) \mathrm{m}$ for $200 \mathrm{hPa}$, and $-10(0) \mathrm{m}$ for $850 \mathrm{hPa}$.

the middle troposphere over the super clusters. The signal of the ISOs is strong over the regions between the Indian Ocean and the dateline. However, if the planetary-scale ISO is dominant, the signal is not confined to these regions but found all over the globe. For example, in the upper-level velocity potential field (Fig. 3 left), after the first passage of the active convective area of the ISO at the end of December, the negative (that is, upper divergent ) maximum still propagated eastward from the dateline toward the Atlantic and crossed the Africa Continent to prepare the second ISO enhancement over the Indian Ocean in early January. The positive (convergent) maximum was also moving around the globe. In early January, over the Indian Ocean around $120^{\circ} \mathrm{E}$, the positive maximum propagated eastward and came back again in early February. A similar feature also can be seen in the lower tropospheric velocity potential fields (Fig. 3, right). However, the wind fields in Fig. 2 have a slightly different character. We cannot easily see the eastward progression of the zonal wind fields in the lower troposphere over the eastern Pacific and Atlantic. At
$200 \mathrm{hPa}$ (Fig. 2, left) the enhancement of the westerlies around $120^{\circ} \mathrm{W}$ is noticeable, which is associated with the enhancement of the easterlies over the western Pacific. This may suggest the enhancement of the east-west circulation resulting from the active convective activity over the western and central Pacific. At $850 \mathrm{hPa}$ (Fig. 2, right) it should be remembered that the easterlies over the western Pacific prior to the periods with maximum westerlies in early January and early February have different characters in both ISOs. Before the first active phase of the ISO, the zonal wind was very weak (less than $5 \mathrm{~ms}^{-1}$ ) over the western Pacific. Sometimes there were westerlies and easterlies. However, before the second active phase of the ISO, the easterlies exceed $5 \mathrm{~ms}^{-1}$ and sometimes reach $10 \mathrm{~ms}^{-1}$.

Figure 4 shows the geopotential fields at $200 \mathrm{hPa}$ (left) and $850 \mathrm{hPa}$ (right). At $200 \mathrm{hPa}$, there are two high anomalies over the western and central Pacific $\left(140^{\circ} \mathrm{E}-180^{\circ}\right)$. These regions correspond to the active convective region associated with the ISO. The standing component is prominent. During the 4month period, there are positive anomalies over the 
300T GANAL

NOV92 - FEB93

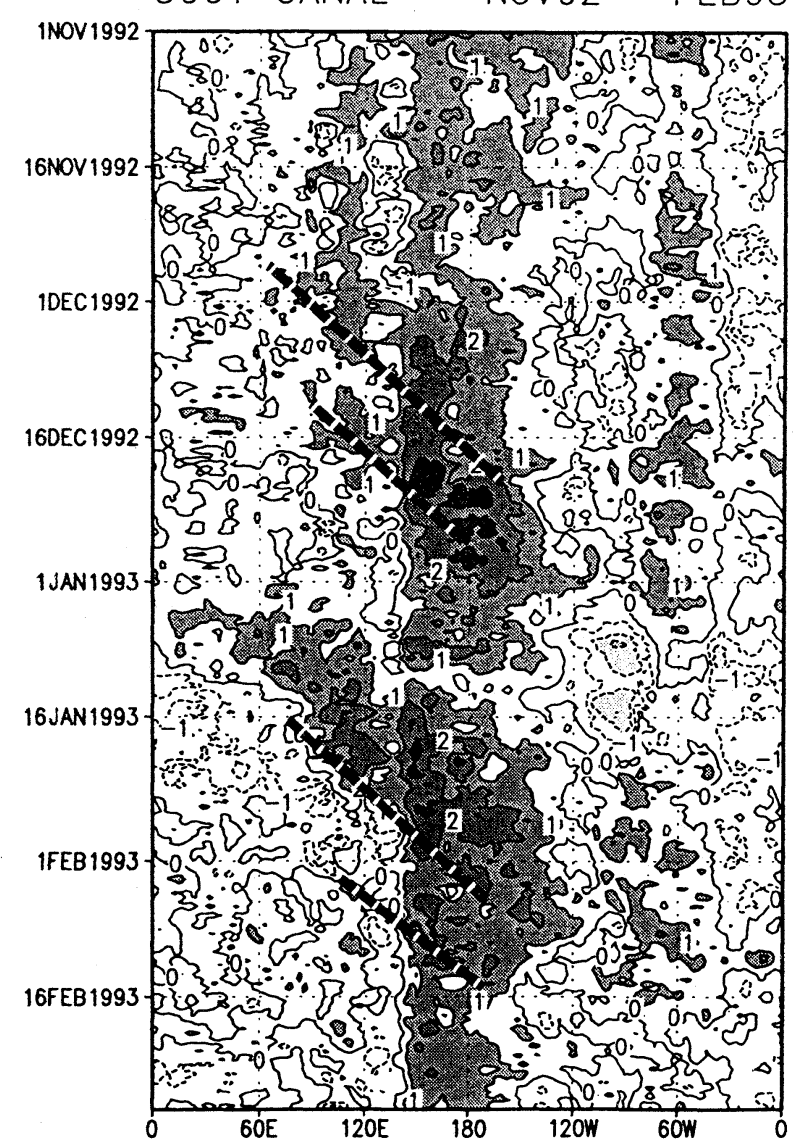

GrADS: COLA/UMCP

Fig. 5. Time-longitude section of the temperature at $300 \mathrm{hPa}$. The offset is $-32^{\circ} \mathrm{C}$. Light (dark) shading denotes the area of less (more) than -33 $(-31)^{\circ} \mathrm{C}$.

western and central Pacific and over the Amazon. There are negative anomalies over the rest of the regions. The traveling component is found over the limited longitudinal width between $60^{\circ} \mathrm{E}$ and $140^{\circ} \mathrm{E}$ and temporal duration between 10 and 30 January, which is associated with the second ISO. Overlaying Fig. 4 with the convective activity (Fig. 1), we notice that at $200 \mathrm{hPa}$, the positive (negative) anomaly is located east (west) of the active convective region and at $850 \mathrm{hPa}$, the negative (positive) anomaly is located east (west) of the active convective region. That is, the second ISO resembles the equatorial Kelvin wave.

Figure 5 shows the temperature fields at $300 \mathrm{hPa}$. The heavy shading denotes the area warmer than $-31^{\circ} \mathrm{C}$. There are warm anomalies over the western and central Pacific, which are the same areas as seen in the upper-level geopotential field (Fig. 4). These warm anomalies may reflect the warming due to the latent heat release by the large-scale convective activity. From Figs. 3-5 we may spec- ulate that the correlation between the upward motion and the temperature is positive over the western Pacific, suggesting the energy conversion from the available potential energy to the eddy potential energy to maintain the ISOs. However, this is not true over the Indian Ocean and the maritime continent $\left(60^{\circ} \mathrm{E}-130^{\circ} \mathrm{E}\right)$. The correlation of the upper divergence and the temperature at $300 \mathrm{hPa}$ over the regions is almost 0 , showing no energy conversion from the available potential energy to the eddy potential energy.

Figure 6 show the sea surface temperature. The left figure is the SST and right one is the anomalous SST (seasonal SST is removed). The warm SST regions extend from the Indian Ocean to the central Pacific. The cold SST are found over the eastern Pacific. During the 4-month period of the TOGACOARE IOP, the seasonal trend is clearly seen over the western Pacific and the eastern Pacific, showing the cooling (warming) trend over the western (eastern) Pacific from $29.5^{\circ} \mathrm{C}\left(24.5^{\circ} \mathrm{C}\right)$ in November to $28.5^{\circ} \mathrm{C}\left(27.0^{\circ} \mathrm{C}\right)$ in February. A large zonal gradient of the SST between the western Pacific and the eastern Pacific during November and December exists and it gradually reduces with time.

Although the signal is not so evident, we may notice that the SST propagates eastward. The first warming SST of $28.5^{\circ} \mathrm{C}$ can be found over the Indian Ocean $\left(90^{\circ} \mathrm{E}\right)$ in late November. Then the warm SST of $29.5^{\circ} \mathrm{C}$ is found at $130^{\circ} \mathrm{E}$ in early December, at $150^{\circ} \mathrm{E}$ in $5-10$ December and at the dateline in the middle of December. A cool SST episode followed the warm SST progression. Then another warming is found over the Indian Ocean in early January, at $130^{\circ} \mathrm{E}$ in $15-20$ January and at the dateline around the end of January. A cool SST is also found after this warm event. The above feature is more clearly found in the anomalous SST. The period of the TOGA-COARE IOP is characterized as an "ENSO-like" period due to the warm SST anomaly (SSTA) over the western Pacific. The anomalous SST shows that the warm SSTA $\left(>1^{\circ} \mathrm{C}\right)$ regions are found over the Indian Ocean and the western to central Pacific. The warm SSTA $\left(>1^{\circ} \mathrm{C}\right)$ over the Indian Ocean can be found around 20 November and early January. These warm SSTA regions moved eastward to reach the dateline in late December and late January, respectively. As is shown in the previous figures (Figs. 2-5), the eastward progression of the warmer temperature fields is associated with the active phase of the ISO. The cool SSTA is evident after the warm SSTA events.

\section{c. Is the moisture leading the convection?}

So far we have examined the large-scale behavior of the ISOs by using the zonal wind, temperature, geopotential, and velocity potential field from the GANAL dataset. We have not checked the moisture 
SST ( JMA/NPD) NOV92 - FEB93



SSTA $(J M A / N P D) \quad E Q-5 S$

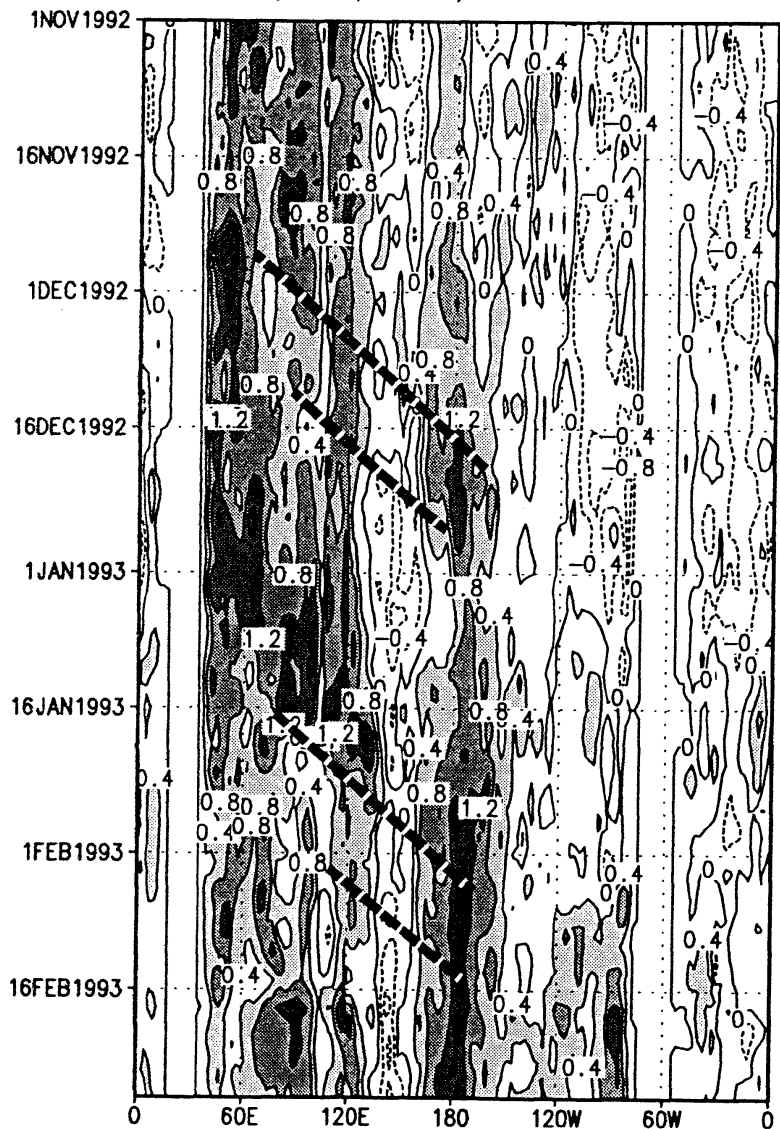

GrADS: COLA/UMCP

Fig. 6. Time-longitude section of the sea surface temperature (SST) (left) and sea surface temperature anomaly (seasonal trend subtracted, SSTA) (right) averaged between the equator and $5^{\circ} \mathrm{S}$. The contour intervals are $0.5(0.4)^{\circ} \mathrm{C}$ for SST (SSTA).

data. There is a hypothesis explaining the maintaining mechanism of ISO, which was introduced by Emanuel (1987) and Neelin et al. (1987), that the anomalous easterlies (the mean easterlies plus the easterlies of an ISO) east of the ISO will enhance the water vapor supply from the sea surface to generate the new convection east of the center convection, which is associated with the ISO, thus leading to the eastward shift of the ISO. To check this hypothesis, we first plot the vertically-integrated moisture or total precipitable water (tpw). The data sources are (1) the GANAL dataset and (2) the SSM/I dataset.

Figure 7 shows the tpw fields along the equator of GANAL (left) and SSM/I (right). In the GANAL tpw, there are high $\left(>60 \mathrm{kgm}^{-2}\right)$ moisture regions over the Indian Ocean $\left(50^{\circ}-90^{\circ} \mathrm{E}\right)$, the western to central Pacific $\left(130^{\circ} \mathrm{E}-150^{\circ} \mathrm{W}\right)$ and the Northern Brazil $\left(60^{\circ} \mathrm{W}\right)$. On contrary, there is a dry $\left(<40 \mathrm{kgm}^{-2}\right)$ region over the eastern Pacific $\left(150^{\circ}-\right.$ $90^{\circ} \mathrm{W}$ ). In the SSM/I tpw, which is only available over the sea, there are also wet regions over the Indian Ocean and the western-to-central Pacific. But the value does not exceed $55 \mathrm{kgm}^{-2}$, which is smaller than the GANAL tpw over these wet regions by about $5-10 \mathrm{kgm}^{-2}$. The dry region is found in the eastern Pacific, as is found in the GANAL tpw. In connection with the ISO-scale phenomena, these two figures can pick up the same characteristic feature. We notice in both the GANAL and SSM/I tpws that there are two eastward-moving wet regions from the Indian Ocean to the dateline, which is the signal of the major ISOs during the TOGA-COARE IOP. However, if we look at the figure carefully, we find the difference in the temporal variations of the two tpws.

Figure 8 shows the time-longitude section of the GMS IR TBB (left), the SSM/I tpw (middle), and the GANAL tpw (right) averaged between $5^{\circ} \mathrm{S}$ and the equator from $60^{\circ} \mathrm{E}$ to $150^{\circ} \mathrm{W}$ (the GMS data are available from $80^{\circ} \mathrm{E}$ to $160^{\circ} \mathrm{W}$ ) during the passage of the first ISO from December 10 to January 10. For convenience, we draw the convection center line in the tpw figures. First, let us compare the GMS data with the GANAL tpw. We have a wet condition $\left(>60 \mathrm{kgm}^{-2}\right)$ at the active convective area. There is no time difference. If the air is wet, there is a si- 



Fig. 7. Time-longitude section of the total precipitable water (tpw) computed from GANAL data (left) and the tpw data from SSM/I data (right). The dark region denotes the area with greater than $60 \mathrm{kgm}^{-2}$.

multaneous occurrence of the convection. But if we compare the GMS data with the SSM/I tpw, we find that the wet condition is first established before the passage of the active convection of the ISO. For example, the convection is active between $120^{\circ} \mathrm{E}-180^{\circ}$ around December 21. The GANAL tpw becomes a maximum at the same time. However, the SSM/I tpw becomes a maximum much earlier, around December 12-16, about 5-10 day earlier than the passage of the active convection. Figure 9 shows the second ISO case from January 10 to February 10. In this figure, we can see that there is a phase difference between the GMS data and GANAL tpw, showing that both the GMS tpw and the SSM/I tpw patterns look similar. The moisture is leading the convection by about 5 days or so over the western Pacific $\left(120^{\circ} \mathrm{E}-160^{\circ} \mathrm{E}\right)$.

Which tpw data (GANAL or SSM/I) in December of 1992 is more representative of the real atmosphere? One possibility for little phase lag in the GANAL tpw is that the GANAL data modifies the moisture fields by using the empirical method from the GMS IR imagery. We suspect that the modifi- cation is so strong that it eliminates the phase lag (From Dr. A. Nomura, personal communication). We hope we can check it by using the numerous TOGA-COARE data, such as from the Integrated Sounding System (ISS) or upper sounding data. The current available moisture data of ISS has a bias in the lower troposphere and is now being processed for the final dataset.

Is the evaporation-wind speed feedback hypothesis confirmed from the data? Before discussing the question, we first examine the wind speed over the equatorial western Pacific $\left(120^{\circ} \mathrm{E}-180\right)$ in Fig. 2. At $850 \mathrm{hPa}$, the zonal wind is weak $\left(<5 \mathrm{~ms}^{-1}\right)$ around December 1 to 16 before the enhancement of westerlies associated with the first ISO. After the passage of the first ISO, there appear moderate easterlies (about $5-10 \mathrm{~ms}^{-1}$ ) until the enhancement of westerlies corresponding to the second ISO in late January. The evaporation $E$ from the sea surface can be written by the bulk formula in the following way:

$$
E=\rho C_{D}(|v|)|v|\left(q^{*}(T s)-q_{a}\right),
$$

where, $\rho$ : air density, $C_{D}$ : bulk coefficient, $|v|$ : 


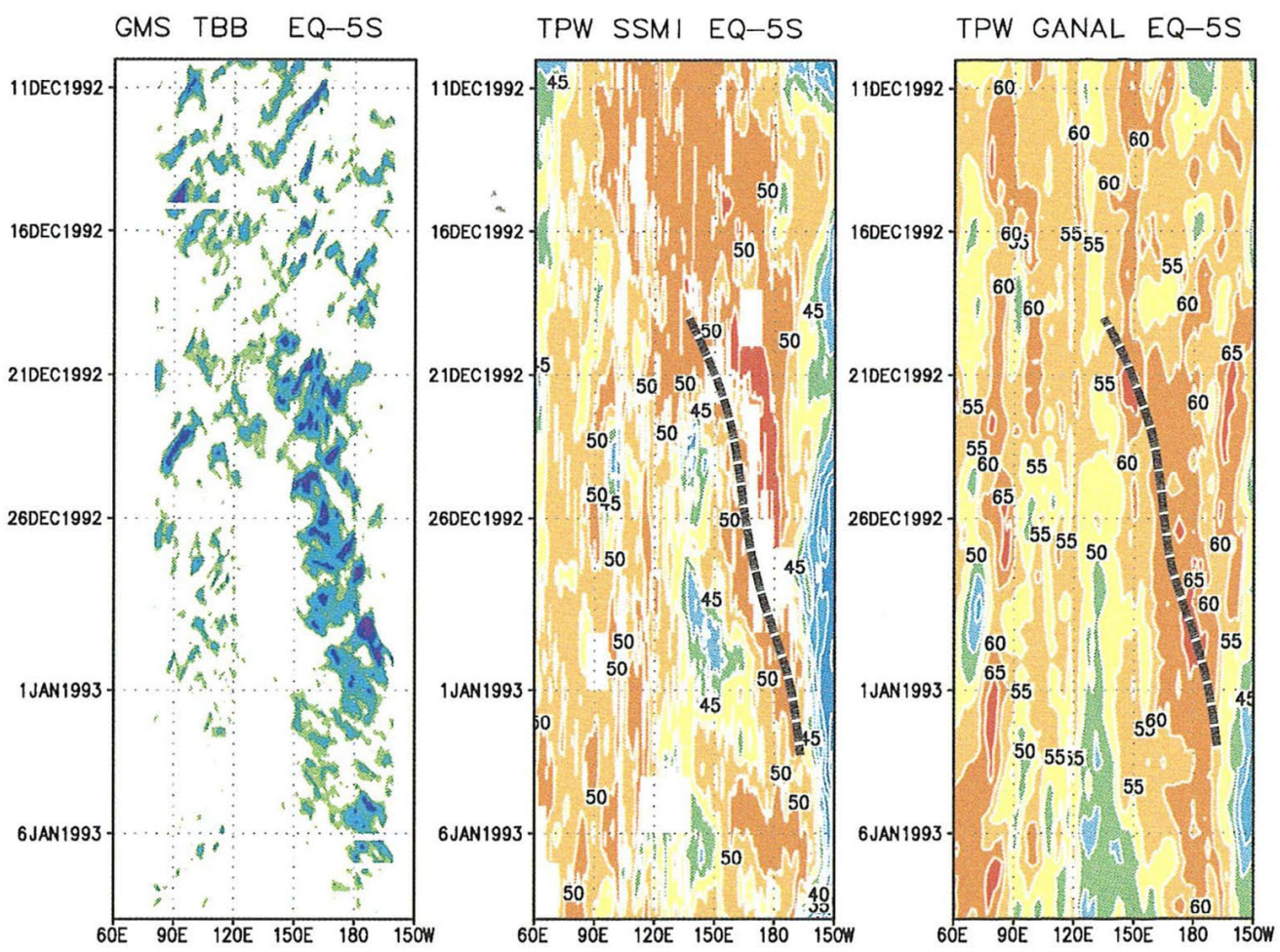

GrADS: COLA/MMCP

Fig. 8. Time-longitude section of the GMS IR TBB dataset (left), tpw of SSM/I data (middle), and tpw from GANAL data (right) during the first ISO averaged between $5^{\circ} \mathrm{S}$ and the equator. For GMS, shading information is the same as in Fig. 1. For tpw, the unit is $\mathrm{kgm}^{-2}$. Thick dashed lines show the location of the maximum convective activity defined by GMS IR TBB (left).
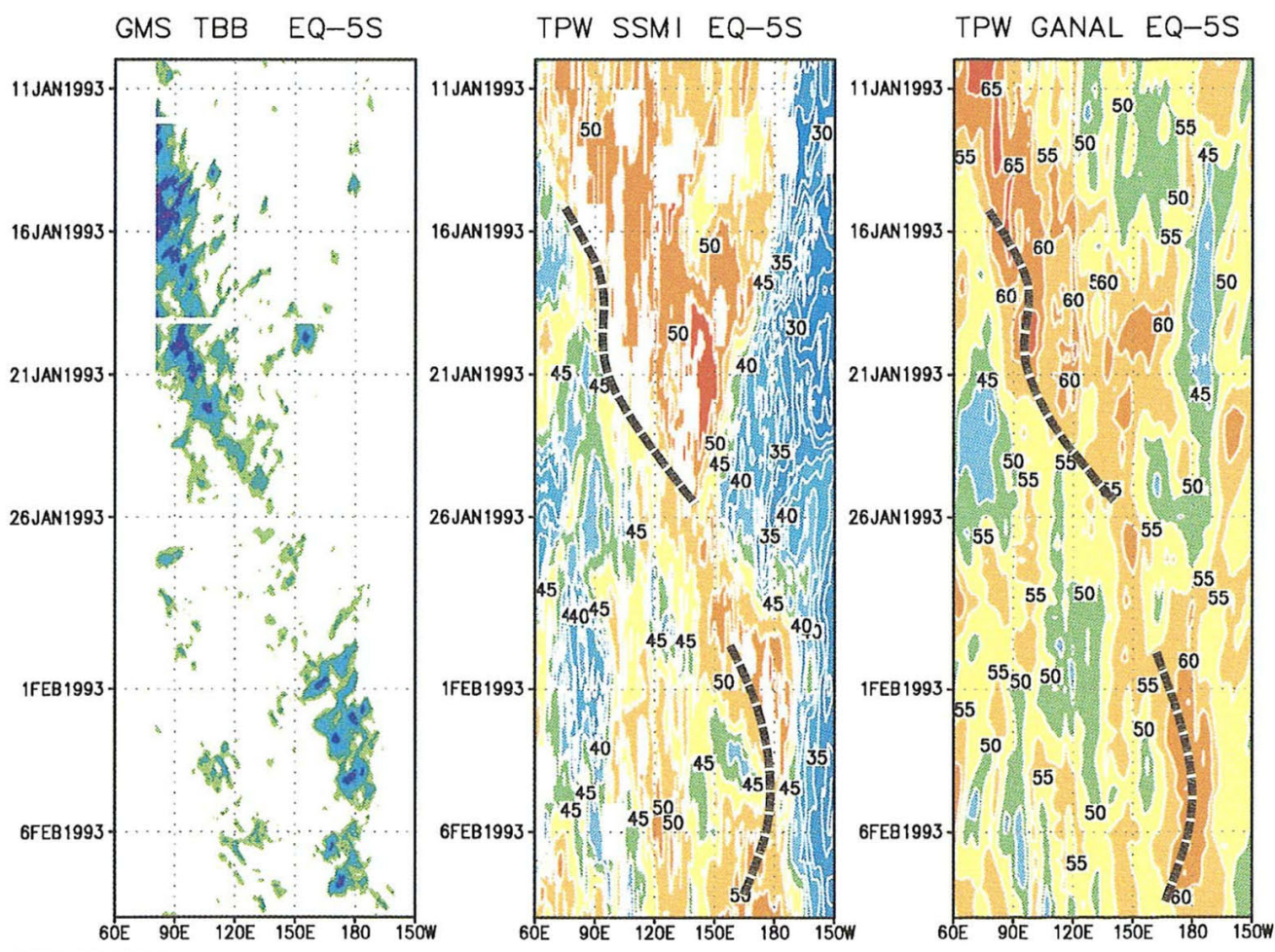

Fig. 9. Same as Fig. 8, except for during the second ISO. 
GrADS: COLA/UMCP

SST DEC92 5S-EQ



JAN93 5S-EQ



Fig. 10. Similar to Fig. 8, except for the sea surface temperature with $0.5^{\circ} \mathrm{C}$ contour interval during the first (left) and second (right) ISO. surface wind speed, $q^{*}(T s)$ : saturated specific humidity at the sea surface temperature and $q_{a}$ : specific humidity of the air, respectively. Note that the evaporation $E$ is affected not only by $|v|$ but also by $C_{D}$, and $\left(q^{*}(T s)-q_{a}\right)$. From Fig. 2 and Fig. 6 , we find that the GANAL tpw data do not support the evaporation-wind speed feedback hypothesis, because of little phase lag between moisture and convection. Before the first ISO arrives, the zonal wind speed is weak and the tropospheric moisture is large. This tells us that the evaporation does not come from $|v|$, but from $C_{D}$ and $\left(q^{*}(T s)-q_{a}\right)$. Liu et al. (1979) theoretically computed the wind speed dependency of $C_{D}$, and found that $C_{D}$ increases as the surface wind speed decreases to the weak condition. He mentioned that in the typical case over the western tropical Pacific with a coefficient of $1.8 \times 10^{-3}$, the latent heat flux is about $40 \%$ higher than the value given by a neutral coefficient of $1.3 \times 10^{-3}$. Bradley et al. (1989) confirmed the study of Liu et al.(1979) from their observation that $C_{D}$ increases as the wind speed becomes weak. To estimate the contribution of $\left(q^{*}(T s)-q_{a}\right)$, we show Fig. 10. The figure represents the SST during the first (a) and second (b) ISO period. The SST in the figure resembles the SSM/I tpw, shown in Fig. 8 and 9. The warm SST usually corresponds to the wet tpw over the western and central Pacific. This correspondence suggests that the SST is also leading the convective activity. This warm SST may be due to insolation under the clear sky with a calm wind condition (See the next sub-chapter d.) As the moisture at the surface according to GANAL data does not change much (not shown), the SST is an important contributor to the change of $q^{*}(T s)-q_{a}$. At $1000 \mathrm{hPa}$, we may have a saturated specific humidity of $23.5(26.4) \mathrm{gkg}^{-1}$ at $28^{\circ} \mathrm{C}\left(30^{\circ} \mathrm{C}\right)$ of SST. A two degree difference of the tropical SST from $28^{\circ}$ to $30^{\circ} \mathrm{C}$ causes about a $12 \%$ change in the surface evaporation if $q_{a}$ does not change.

In that sense, the moistening process is not directly related to the increasing wind speed. We may have to consider the effect of a $C_{D}$ increase under the weak wind speed condition and with SST warm- 


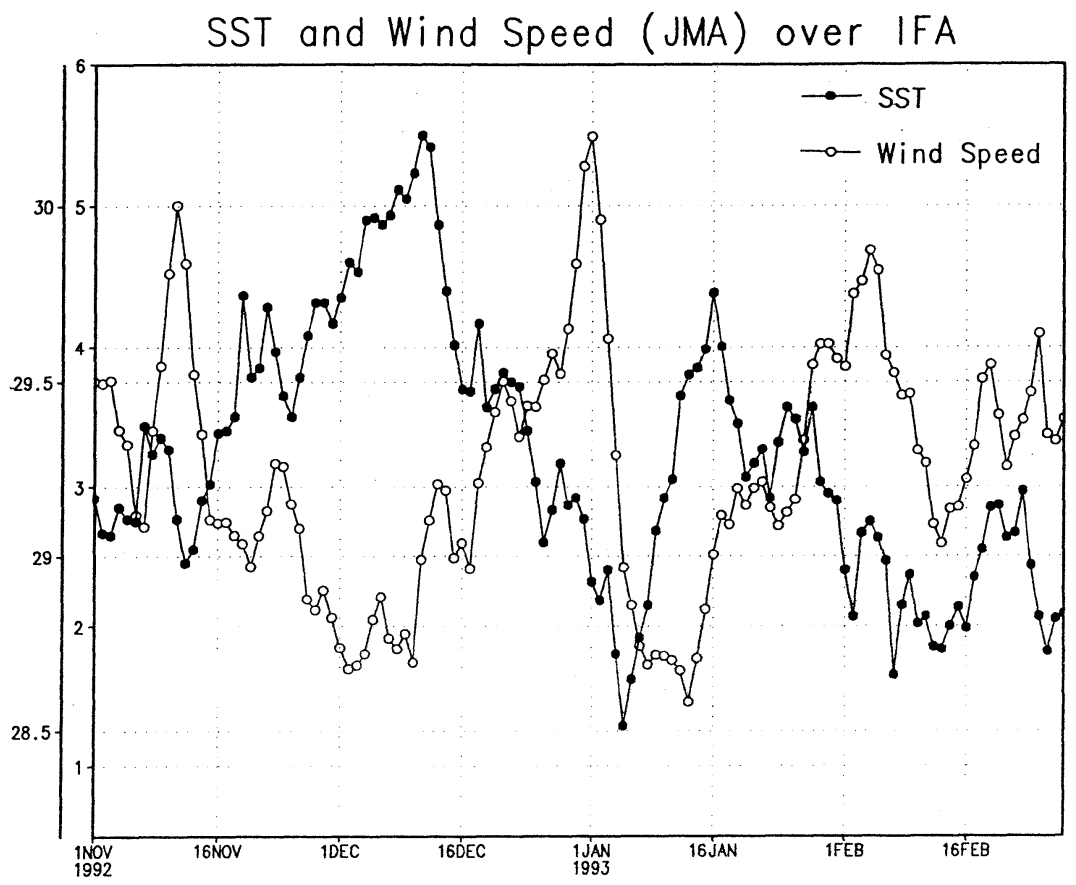

GrADS: COLA/UMCP

Fig. 11. Time-series of SST (closed circle) and surface wind speed (open circle) over the IFA region, defined as a box averaged $150^{\circ} \mathrm{E}-160^{\circ} \mathrm{E}$, and the equator and $5^{\circ} \mathrm{S}$.

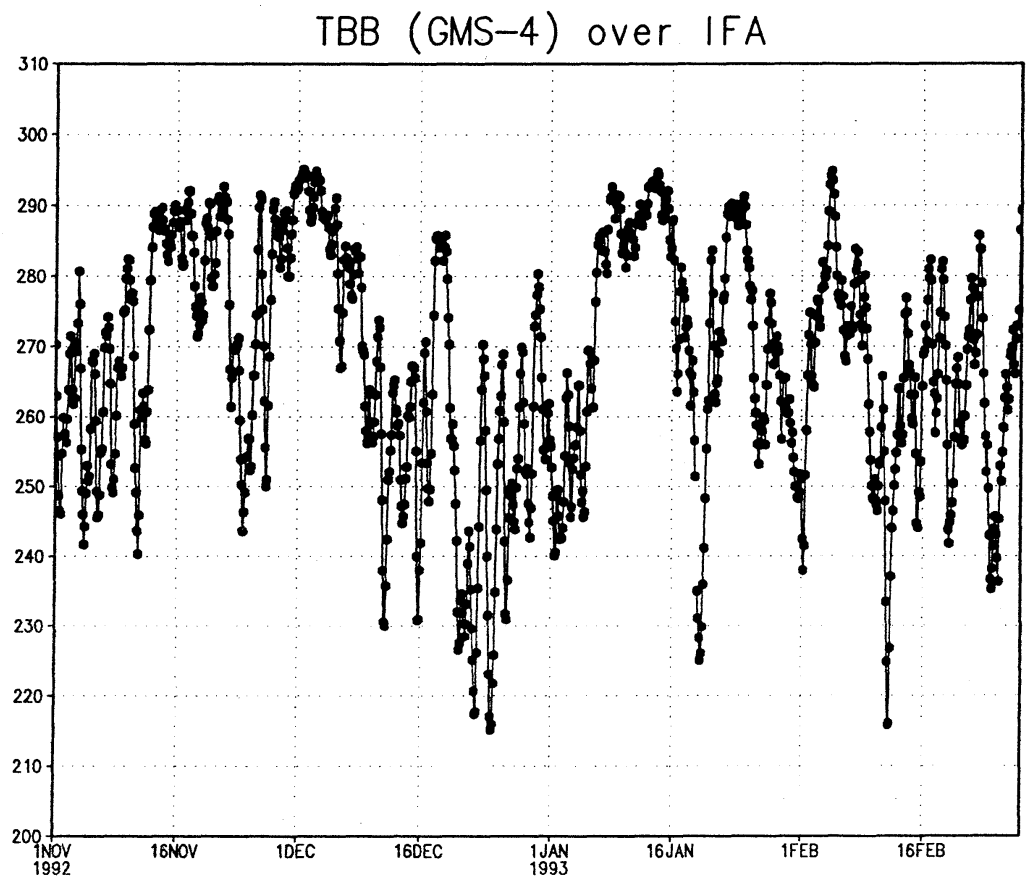

GrADS: COLA/LACP

Fig. 12. Same as Fig. 11, except for GMS IR TBB mean over the IFA. Note that the cloud top temperature is cold when the sky is covered by clouds.

ing.

d. Temporal variations of the surface fluxes over IFA In the last sub-session, we showed the phase relationship between the tpw or SST and the convective activity. In this sub-chapter we concentrate the discussion on the surface fluxes which are responsible for the SST or moisture change over the Intensive Flux Array region where the most extensive flux observation network was performed during the TOGA-COARE IOP. 


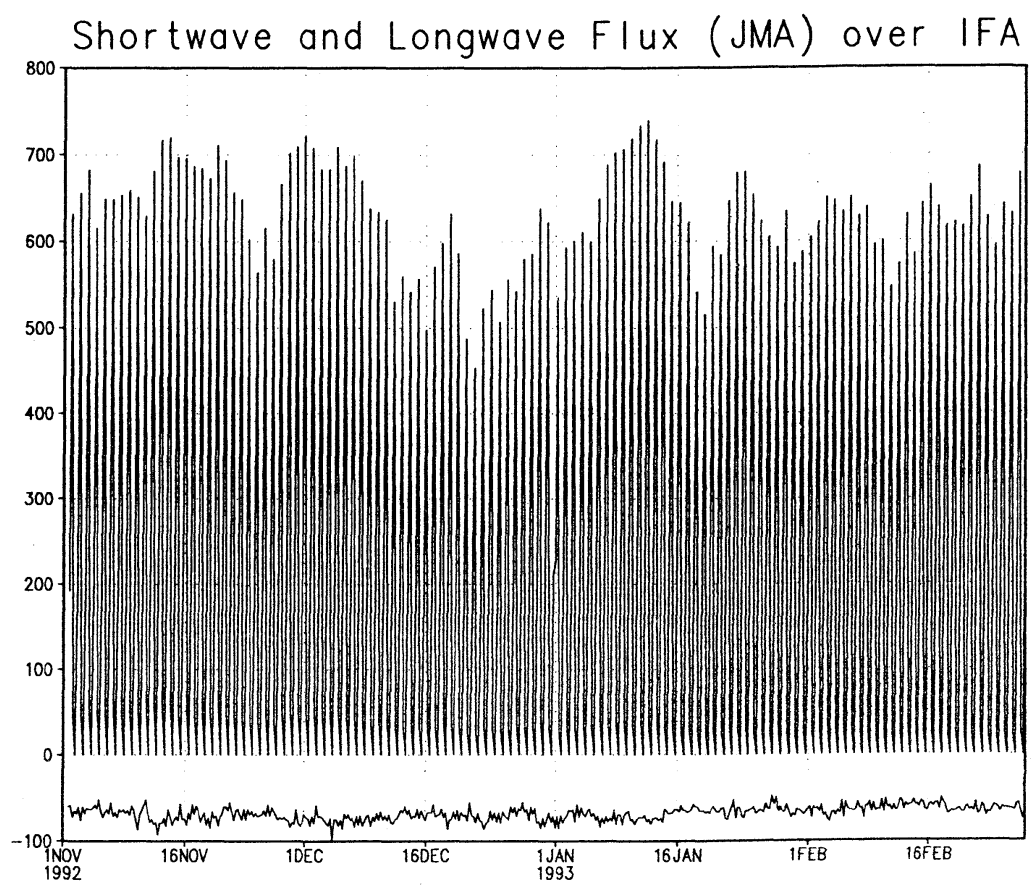

GrADS: COLA/UMCP

Fig. 13. Same as Fig. 12, except for the net shortwave (positive: downward) and the net longwave flux (negative: upward).

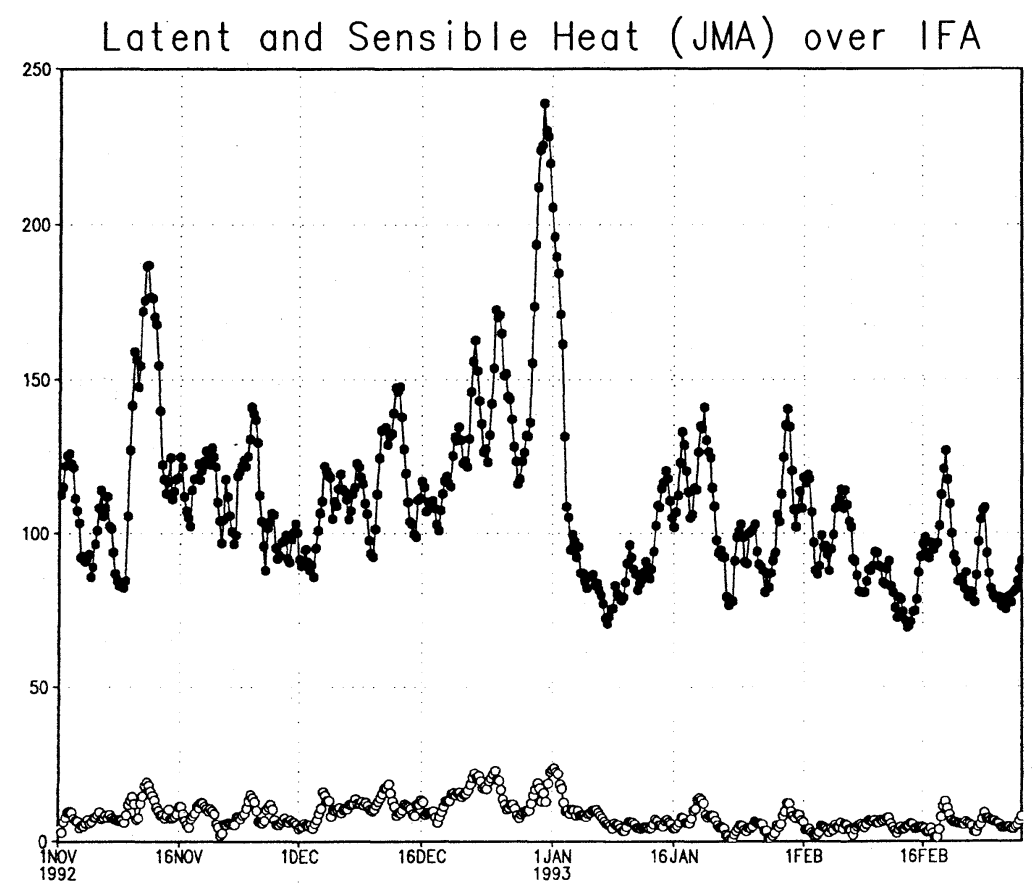

GrADS: COLA/UMCP

Fig. 14. Same as.Fig. 12, except for the sensible heat (open circle, positive: upward) and latent heat (closed circle, positive: upward) flux.

Figure 11 shows the temporal variations of the SST and the wind speed over the IFA region. The IFA region in this paper is defined as the box between $150^{\circ} \mathrm{E}$ and $160^{\circ} \mathrm{E}$, the equator and $5^{\circ} \mathrm{S}$. The wind speed has a maximum around early January and early February, when the low-level westerlies of the ISO prevails over the domain (see Fig. 2). Before the wind speed has a maximum, the SST achieves its warm peak around 10 December and middle of January. The SST leads the wind speed by about 




GrADS: COLA/MMCP

Fig. 15. Total flux by adding 4 terms shown in Figs. 13 and 14 at the surface. Smoothed line is the time-averaged line of the net flux. A positive value denotes the direction from the atmosphere to the ocean.

20 days. Figure 12 shows the GMS IR TBB over the IFA region. The cold TBB or active convection is found around 23 December of the first ISO. The minimum of TBB associated with the second ISO is not clear. The phase difference between SST maximum and the convection for the first ISO is about 12-13 days.

The phase relationship between the SST and the eastward-moving ISO has been investigated in several papers (e.g. Kawamura (1988), T. Murakami (1988)). They showed that the SST leads the convection associated with the eastward-moving ISO. Kawamura (1988) showed that the phase difference is about $140^{\circ}-170^{\circ}$, implying that the SST is leading by about 10-20 days. T. Murakami (1988) showed a 10-15-day difference. Our result of 12-13 days agrees well with these earlier studies.

Comparing Fig. 11 with Fig. 12, we notice that the warming up of the SST is associated with the condition under the clear sky (high TBB around 280$290^{\circ} \mathrm{K}$ ) and the low wind speed. The SST started warming around 10 November. Before warming, the TBB is low and disturbed with high wind speed. After 10 November, the sky becomes clear and the wind speed drastically reduced. Then the SST gradually warmed from $29^{\circ} \mathrm{C}$ to $30.2^{\circ} \mathrm{C}$ in 11 December. It took about a month. The warming rate is about $0.04^{\circ} \mathrm{Cday}^{-1}$. The SST rise was interrupted during 20-25 December, when the TBB became cold and the wind speed became a little high. When the SST reached its peak, the wind speed began to increase and the convective activity also, which reflects the disturbed state of the first ISO, to decrease the SST so rapidly. After the passage of the first ISO, the wind speed decreased just after the peak on 1 January of $5.5 \mathrm{~ms}^{-1}$. The convective activity weakened and a calm and clear situation prevailed. Then the SST started warming up again. For the second ISO case, it took only 11 days for the SST to warm up from $28.5^{\circ} \mathrm{C}$ in 5 January to $29.7^{\circ} \mathrm{C}$ in 16 January. The warming rate is about $0.1^{\circ} \mathrm{Cday}^{-1}$, which is a much larger rate compared to the rate of the first ISO. After 16 January, the SST started cooling down with an increase in the wind speed and a lower TBB. The phase relationship changed and became in phase in February.

We will examine the above tendency of the SST, wind speed and TBB by using the surface flux dataset produced by the JMA/NPD. The surface flux dataset has four variables, net shortwave (SW) and longwave (LW) flux, sensible (SH) and latent heat (LH) flux. For the first two quantities, the positive value denotes the direction from the atmosphere to the ocean. For the last two, the positive value means a flux from the ocean to the atmosphere. Figures 13-15 show the time series during the TOGACOARE IOP of these quantities. Figure 13 is the SW and LW flux over the IFA region. The SW flux varies from 0 at night to about $600 \mathrm{Wm}^{-2}$ at day time. The LW flux is about $-80 \mathrm{Wm}^{-2}$. The time 
average of the SW flux during the TOGA-COARE IOP is about $250 \mathrm{Wm}^{-2}$. Figure 14 is the $\mathrm{LH}$ and SH flux over the IFA region. The closed circle is the $\mathrm{LH}$ and the open circle is for the SH. The LH has a distinct peak of about $240 \mathrm{Wm}^{-2}$ in 1 January. The peak of the LH corresponds to the peak of the surface wind speed shown in Fig. 11. The temporal variation of the LH is mainly correlated with the change of the surface wind speed except for the period of February, because the formula to calculate the LH is based on the bulk method, which was described in (1). But, as we discussed in Session 3-c, the LH is also related with the $C_{D}$ and the SST. High surface wind speed is definitely responsible for the high LH during the first ISO. However, for the second ISO, even though the surface wind speed is strong (Fig. 11) at about $4.7 \mathrm{~ms}^{-1}$, the $\mathrm{LH}$ is not high. This may be due to the smaller saturated specific humidity associated with the cooler SST over the domain, as is shown in Fig. 11.

Figure 15 is the time change of the total flux (SW+LW-SH-LH) over the IFA region. The positive value means the ocean receives energy from the atmosphere. The 2-day running mean is also drawn in this picture. From the figure we find that there is a positive total flux at the surface over the IFA region of about $+50 \mathrm{Wm}^{-2}$, suggesting that the ocean receives energy to warm up the ocean, not considering ocean dynamics such as advection, mixing or diffusion in the ocean. It is interesting to note that the total flux became negative between 11 December and 30 December during the passage of the first ISO. The SST dropped during this period, as is shown in Fig. 11. During the second ISO, the SST also dropped in late January, but the total flux was positive. We speculate that the ocean response may be different in these two ISOs.

\section{Summary}

We have presented the behavior of the convective activity and other meteorological variables such as divergence and velocity potential, associated with the intraseasonal oscillation during the TOGACOARE IOP.

The main findings in this study are as follows.

(1) There were two major ISOs during the TOGACOARE IOP. One was in December, and the other in January. We confirmed that there is a hierarchic structure of the tropical convection; planetary-scale ISO, eastward-moving synoptic-scale super cluster, and westward-moving meso-scale cloud cluster.

(2) The maximum of the tpw delineated from the SSM/I data is leading the convective activity from the GMS IR TBB data by about 5-10 days. The SST is also leading the convection about 12-13 days, which is the same as for previous results. However, in December of 1992, there is very little phase difference between the total precipitable water (tpw) of the global analysis dataset (GANAL) produced by the Japan Meteorological Agency and the convective activity from GMS IR TBB data.

(3) The SST change is closely related with the ISO passage. The clear sky and the calm wind condition leads to the warming up the SST east (that is, before the passage) of the active convection associated with the ISO. During the passage of the active convection associated with the ISO, the SST decreases due to less insolation from the sun and the enhanced latent heat flux from the sea surface under the disturbed wind condition.

\section{Acknowledgments}

We wish to express our special thanks to Prof. A. Sumi, Center for Climate System Research of University of Tokyo for encouragement throughout the study.

We thank Dr. Atsushi Numaguchi for providing the SSM/I data and Dr. G. Kiladis for providing the OLR data during the TOGA-COARE IOP. We also thank Dr. Yoshinobu Nikaidou for informing us about the surface flux data of JMA, and Dr. Masahide Kimoto for providing the surface flux data produced by the atmospheric GCM operational model in JMA.

Grateful acknowledgment is made to Dr. M. Fiorino in the Lawrence Livermore National Laboratory of University of California for providing powerful graphic software "GrADS"; most of the figures in this study were plotted by this software.

\section{References}

Bradley, E.F., P.A. Coppin and J.S. Godfrey, 1989: Measurements of sensible and latent heat fluxes in the western equatorial Pacific Ocean. J. Geophys. Res. suppl., 96, 3375-3389.

Emanuel, K.A., 1987: An air-sea interaction model of intraseasonal oscillations in the tropics. J. Atmos. Sci., 44, 2324-2340.

Hendon, H.H. and B. Liebmann, 1994: Organization of convection within the Madden-Julian oscillation. $J$. Geophys. Res., 99, 8073-8083.

Kawamura, R., 1988: Intraseasonal variability of sea surface temperature over the tropical western Pacific. $J$. Meteor. Soc. Japan, 66, 1007-1012.

Liu, W.T., K.B. Katsaros and J.A. Businger, 1979: Bulk parameterization of air-sea exchanges of heat and water vapor including the molecular constraints at the surface. J. Atmos. Sci., 36, 1722-1735.

Murakami, T., 1988: Relationship between sea surface temperature and outgoing longwave radiation on intraseasonal time scales. (Japanese), Tenki, 35, 715722 .

Nakazawa, T., 1986: Mean features of 30-60 day variations as inferred from 8-year OLR data. J. Meteor. Soc. Japan, 64, 777-786.

Nakazawa, T., 1988: Tropical super clusters within intraseasonal variations over the western Pacific. $J$. Meteor. Soc. Japan, 66, 823-839. 
Neelin, J.D., I.M. Held and K.H. Cook, 1987: Evaporation-wind feedback and low frequency variability in the tropical atmosphere. J. Atmos. Sci., 44, 2341-2348.

Takayabu, Y.N., 1994a: Large-scale cloud disturbances associated with equatorial waves. Part I: Spectral features of the cloud disturbances. J. Meteor. Soc. Japan, 72, 433-449.

Takayabu, Y.N., 1994b: Large-scale cloud disturbances associated with equatorial waves. Part II: Westwardpropagating inertio-gravity waves. J. Meteor. Soc. Japan, 72, 451-465.

\section{TOGA-COARE IOP 期間中の季節内振動}

\section{中澤哲夫}

(気象研究所)

1992 年 11 月から 1993 年 2 月までの TOGA-COARE IOP 期間中の季節内振動 (ISO) に伴う対流活動 及び発散、速度ポテンシャル、全可降水量 $(\mathrm{tpw})$ などの気象変量の振る舞いを調べた。

IOP 期間中には $2 つ の$ 主要な ISO があり、一つは 12 月に、もう一つは 1 月に見られ、プラネタリー・ス ケールの ISO 、東進する総観規模のスーパークラスター、そして西進するメソ・スケールのクラウドクラ スターという、熱帯対流活動の階層構造が確認された。いずれの ISO も二つのスーパークラスターを伴っ ていた。SSM/I デー夕から求められた tpw の極大值は、静止気象衛星 GMS の IR TBB デー夕の対流活発 域よりも5 10 日ほど先行している。海面水温も、対流活発域におよそ12 13 日先行しており、これまで の解析結果と同様であった。

海表面における放射収支についても調べた。海面水温 $(\mathrm{SST})$ 变化はISO の通過と密接に関係しており、ISO 対流活発域の東側 (すなわち対流活発域の通過前) での晴天、静稳状態がSST 上昇を導いている。対流活発域 の通過中に日射の減少と風のじょう乱状態による海表面からの潜熱フラックスの増大のためSST は下降する。 